\title{
Feminism and Gender-Neutral Language: Between Systems and Effects
}

\author{
Mojca Šorli, Faculty of Arts, University of Ljubljana, \\ and Institute for Slovenian Literature and Literary Studies ZRC SAZU, \\ Ljubljana, Slovenia
}

\begin{abstract}
As much as a glimpse into the prevailing cultural patterns, within which current gendered social-linguistic bickering takes place, can also contribute to a tolerant and inclusive discussion of "linguistic subversion" (Jogan, 2018).

The power of form /.../ is that very symbolic power that enables power to fully realise itself by concealing itself as power and letting everyone acknowledge it, approve of it, and accept it precisely because it appeared as universal - a universality of mind and morals (Bourdieu, 200I, translation by M. $\check{S}$.).
\end{abstract}

\section{Introduction}

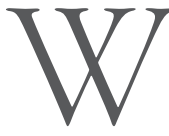

hile the first quote refers to "bickering", as some have labelled the public discussion that took place in 2018 and 2019 about gender-neutral language and how to limit its androcentricity, the second quote answers some key questions about the relation between the symbolic and the universal, on the one hand, and the distribution of social power, on the other. These questions are also central to discrimination in language as part of a wide range of aspects of inequality and social marginalisation of individual groups. The present article and the author's previous work on gender-neutral language in Slovenia are the result of noticing that on the discursive level, especially in less formal discourse, but also in institutionalised discussions about gender and language, the rights of socially disadvantaged groups are all too often disrespected, including 
the right to question culturally assimilated "truths". As a social semiotic and a symbolic code that determines the ways we think about someone or something, language is an important social institution and a key battlefield for equality that must remain open to activist intervention. In terms of gender-neutral language (hereinafter GNL), ${ }^{1}$ it makes more sense to discuss what speakers do with language in social interaction than what constitutes language and its systemic aspects. The conceptualisation of language outside its user is problematic because language is primarily a field of action and social practices. According to Tuldava, discourse, as the most important social aspect of language, is a pragmatic process dealing with meaning (Verdonk, 2002, p. 18; Widdowson, 2004, p. 8) in the sense of interactive events that have meaning and that posit "agency". As such, discourse determines the balance of power between individual participants. Critical discourse analysis (CAD) rejects the assumption about the neutrality of science (Van Dijk, 2008), as scientists are also (or especially) part of social structures that establish important balances of power. This is why (critical) analysis of academic discourse has been central to CAD and other linguistic studies across the world in recent years. For Fairclough (1992, p. 128), a critical linguist, discourse is a special way of constructing the subject matter that includes rules about genres. For Kress (1989, p. 7), discourses are "systematically organised sets of statements which give expression to the meanings and values of an institution" and include a variety of genres. However, it was not until the advent of corpus linguistics, which made it possible to examine large quantities of language data, that true (quantitative and qualitative) discourse analysis became possible. In a narrow linguistic sense, discourse can be understood simply as a type of text that entails identifying conventional patterns of language use. The longest tradition among approaches to gender and language must be recognised in (variational) sociolinguistic analyses (Kranjc, 2019, pp. 396-397), which were based on considerations of language as a product of the individual's personal sociodemographic circumstances. In the following sections, we will observe GNL particularly as it is revealed at the intersection of feminism, linguistics and education. In doing so, we will touch upon various aspects of education, such as teaching materials, language resources and academic discourse about language. The level of the implementation of GNL at the discourse level in a range of educational environments will be examined.

I Initiatives to limit gender disproportion come from many international and supranational institutions. Guidelines and policies for GNL (gender-neutral language, also gender-fair or gender-sensitive language) are an integral part of gender equality policies (UN, UNESCO, European Parliament and others). 


\section{A Brief Overview of the History of GNL in Slovenia and Abroad}

It is important to note that specifically addressing the topic of gender equality began in feminist linguistics and in women's studies of the 1970s, producing the strongest traditions in France and the USA. A ground-breaking work about gender categories in language from this period is Language and Woman's Place by Robin Lakoff from 1975, although the author's binary oppositional conceptualisation of gender and gender difference is obsolete from today's perspective. Another book, Man Made Language by Dale Spender from I980, also gained a lot of attention. The icon of French feminism, Simone de Beauvoir, wrote: "Man is defined as a human being and a woman as a female - whenever she behaves as a human being she is said to imitate the male" (in Moran \& Mooney, 2002, p. 479). Among the younger generation of French feminists who strongly insisted that every representation, be it male or female, is first rooted in language and only then in politics, culture, economy and history are the most prominent theoreticians and philosophers, e.g. Luce Irigaray, Hélène Cixous and the Bolgarian-French semiotician Julija Kristeva, who were particularly concerned with language reform. However, de Beauvoir's quote remains at the centre of the polemical debates that have emerged time and again over the decades, and that are likely to continue, as indicated by recent discussions about language (in)equality in Slovenia and abroad. Certain initiatives that took place in the past (Žagar \& Milharčič Hladnik, 1996; activities of the Ministry of Education, Science and Sport and the Office for Women's Politics; Stabej \& Mihovar Globokar, 1995, see Umek, 2008, p. 59; Government Office for Legislation, 2004/2008/2018; Commission for Women in Science (Šribar), 2010; for an overview of the guidelines to date see Dobrovoljc \& Stabej, 2019), were followed by a period of absence of public debate until the decision of the Senate of the Faculty of Arts of the University of Ljubljana on 25 April 2018 to promote GNL in the faculty's rules and regulations. This discussion generated wide public and media interest and went on for several months. ${ }^{2}$ Interestingly, the part of the discussion concerning linguists - who soon formed two opposing camps - was somewhat overshadowed by social and philosophical reflections on (grammatical) gender. Like two decades earlier, the first camp strongly disapproved of the politically-motivated language intervention, while the second camp saw the need for gender neutralisation of language and discourse as advocated by some proponents (linguists, social scientists and post-structuralists). Furthermore, the second camp argued

2 A round table entitled Gender and L anguage at the Faculty of Arts was held on 23 October 2018, and a discussion entitled Gender and Respect, organised by the Research Centre of the Slovenian Academy of Sciences and Arts, took place on 14 November 2019. 
against the decision intervening in the Slovenian language system; in their view, the intervention could only be about language use and policy. Experts in social sciences and humanities (sociology, philosophy, anthropology, law and others) actively participated in the discussion, confirming the interdisciplinary character of language studies. Among the objections to the initiative of the Senate of the Faculty of Arts that were voiced by people who regard themselves as supporters of gender equality was the exclusion of the transgender group from the (binary) conception of gender; this objection did not, however, come primarily from supporters of transgender-oriented language policy, who apparently understood the discussion mainly as an attempt to denaturalise heteronormative discourse. ${ }^{3}$ Furthermore, the objection to the politics of identity - which presumably characterises the "struggle" for gender equality in language and reinforces discrimination by accepting capitalist liberal ideology and the fragmentation of society instead of eliminating it (e.g. Močnik, 2019; Šribar, 2018; Vuk Godina, 2018) - is based on understanding GNL as a "women's struggle", when in fact it is first and foremost a "social struggle". ${ }^{4}$ This problem is embodied in the "universal" categories of male-centric syntax and the description of, for instance, "human" in a dictionary, indicating a close connection between grammar and social power, especially given the centuries-long tradition of male-as-the-norm. It is often difficult to provide empirical evidence for gender discrimination and male domination in language at the level of its symbolic structures. To understand more broadly the promotion of GNL that can be observed in the post-structuralist (and post-rationalist) approaches to language, it is important both to consider the insights of feminist linguistics and women's studies, as well as the sociolinguistic and sociological perspectives on gender and language, while research is also being conducted on the connections between GNL and gender stereotyping and gender discrimination as part of a broader Marie Curie Initial Training (Language, Cognition, and Gender)' research infrastructure in psycholinguistics.

Helena Drnovšek Zorko: https://www.cep.si/wp-content/uploads/2019/03/Perspectives_DZorko_27.3.2.pdf.

4 Here lies the core problem of the binary conceptualisation of gender: "women's" efforts to achieve equality are first interpreted as a matter of "female identity politics", and only then as a matter that concerns "man" or humanity in general, while for men it is the other way around.

5 http://www.itn-lcg.psy.unibe.ch/content/index_eng.html. 


\section{(Grammatical) Gender as a Category of the Language System}

\section{The (Non-)Neutrality of the Masculine Grammatical Form}

The notion of gender categories in the language system seems very appropriate for illustrating the power that shows itself as universality (Bourdieu, I991, p. 240). It is the existing linguistic norm - i.e. the power that is "recognized by all and thus universal" (ibid.) and seems self-evident, and for this very reason is questioned by the GNL - that justifies the neutrality of the masculine grammatical form. In reality, gender is a complex grammatical category defined on at least four levels: grammatical, lexical or lexical-semantic, referential, and social (gender) (cf. Hellinger \& Bussmann, 200I, pp. 7-II). Here "referential gender" refers to a dynamic referential relation linking linguistic terms to social reality and by no means to a biological characteristic of the referent. Therefore, a (political) choice that critically observes the existing asymmetries in language is quite legitimate. We all actively participate in inclusion or exclusion through our language choices. Which practices are conventional, and how they become conventional, depends on complex social processes, not just in relation to language. As male and female speakers, we differ in the perception of the male grammatical gender as neutral referring to all genders. Slovenian Grammar (Toporišič, 2000), the Slovenian Normative Guide $200 I$ and Slovenian linguistics traditionally state that it is the masculine gender that is neutral in both standard and colloquial language, as well as in dialects. Every language has its own system, which is based on the implicit social agreement. However, "language" is more than just a system. Within the (structural) linguistic-systemic perspective, there is a belief that the problem of gender inequality does not originate in the grammatical gender category and thus cannot be solved by language. Others believe that the problem of GNL must be solved exclusively by the existing linguistic means, i.e. with the linguistic-systemic possibilities of Slovenian. However, the awareness that the neutrality of the masculine grammatical gender not only solves but creates new problems of linguistic hierarchisation has been present for a long time.

\section{"Feminisation" in Language and Society}

"Feminisation" in language, i.e. the use of gendered, or gender-non-neutral, forms (for job titles) in Slovenia dates back to the r990s. In this sense, "feminisation" refers to "the introduction of linguistic feminine forms" with the aim of limiting the androcentricity of language, and, as evident from the source, without conveying any evaluative meaning. This is typical of all field terms (see sense "linguistics" below, $\mathrm{SSKJ}_{2}$ ): 


\section{feminisation}

I. an increasing number of women in places of work or various professions: feminisation of the teaching profession

2. the acquisition of feminine characteristics: feminisation of men was also evident in the way they dressed

- biol. a change of certain characteristics in the male organism to female characteristics; ling. a process by which a word or form changes to the feminine form.

However, by gaining a political profile, the "feminisation of language" has taken on a more negative connotation (the French Academy and conservative linguists are strongly against the "feminisation of French"). By analogy with sense r of "feminisation" above concerning professions and occupations, where, as corpus data show, ${ }^{6}$ feminine forms often acquire a pejorative connotation, such as in tajnica (Eng. secretary) as opposed to tajnik (Eng. secretary), etc., feminine linguistic forms in general hold a non-neutral status through evaluative meaning. Therefore, interventions in traditional nomenclatures and address terms, e.g. gender-specific job titles, do not in themselves bring improvements. As shown by GNL reforms in some languages, they can even be counterproductive, such as forms with a feminine grammatical suffix in French (écrivaine, poetesse) and English (chairwoman, poetess, etc.). The non-neutral, sometimes pejorative meaning of these forms has to do with the way we use language in its evaluative function in the existing power relations. Slovenian is a language with limited possibilities of concealing grammatical gender. However, in languages of this kind as well as in those where it is possible not to express gender (i.e. where syntax is less gender-marked), one can note the dilemma between the decision to "feminise" agent nouns, on the one hand, and to "neutralise" them, on the other. The former makes women more prominent but often carries pejorative connotations, while the latter - using the masculine form as the norm - makes women invisible. For the purpose of this article, however, the first meaning mentioned above is the more interesting one, since empirical data show that it is the most common in standard language and tends to trigger negative evaluation.

6 Lexical and discursive analysis of the use of the lexeme "feminisation" (Šorli, 2020) as an example of a seemingly neutral language - based on the dictionary entry in the Dictionary of Standard Slovenian - reveals strong social connotations and gender asymmetries. The word often appears in contextual environments that portray it as something negative, socially undesirable or as something associated with events, facts or characteristics that encourage negative associations. 


\section{Gender: Language and Society/Culture}

One of the forms of power that increasingly appears as "a universality of mind or morality" (Bourdieu, I99I) is certainly gender being conventionally conceived of in binary terms based on the biological dichotomy between man and woman. However, attributing the "bodily" gender is itself a social decision that has more to do with convention than biology (Fausto-Sterling, 2000, p. 4; Butler, 1993, 1990). For this reason, Perger (2016), for example, uses the term "a person who is socially recognised as a woman/man" in her study of sexism in higher education. Money and some other psychologists use the term "gender" to describe "an identity or self-presentation of a particular individual" (Money \& Ehrhardt, 1972) that is always structured in terms of the demands of society. In contrast, many sociologists (e.g. Lorber, 1994, in Fausto-Sterling, 2000, p. 4) use it to describe a social structure that differentiates between men and women and can drastically interfere with their personal freedom. Fausto-Sterling uses the term "gender" in both of the above meanings and the term "sex" when referring to issues of the body or behaviour: "An individual, therefore, has a sex (male, female, not designated, other); but they engage with the world via a variety of social, gender" and, of course, language conventions. "Gender, then, is definitely in the eye of the beholder. Sex and gender presentation are in the body and mind of the presenter" (ibid., p. 7). Some researchers from the field of social sciences and gender studies have therefore tried to relativise the role of biology. They speak of the social or cultural construct and reject the widespread assumption that gender is based on sex (Antić Gaber, 2014, p. 162). In reality, it is always the social conventions, language or discourse structuring of gender (and sex) that is under discussion, rather than the "natural" characteristics. Feminist (post-structuralist) theory in particular (e.g. Butler, 1990) shows how complex and inherently divided the concept of gender is, proving above all that it is impossible to separate language or the language system from the construction of social reality, which is confirmed by the statement that "every time we speak, our language is the historical effect of language practices, usually controlled by the leading ideology" (Močnik, 2019, p. 357). French post-structuralist theory itself knows different approaches to explaining sex and gender in relation to language. Irigaray, for example, believes in the existence of only masculine sex that "elaborates itself in and through the production of the 'Other"' (in Butler, 2006 [1990], p. 25):

In a move that complicates the discussion further, Luce Irigaray argues that women constitute a paradox, if not a contradiction, within the discourse of identity itself. Women are the "sex" which is not "one." Within 
a language pervasively masculinist, a phallogocentric language, women constitute the unrepresentable. In other words, women represent the sex that cannot be thought, a linguistic absence and opacity. Within a language that rests on univocal signification, the female sex constitutes the unconstrainable and undesignatable (Butler, 2006 [1990], p. I3).

However, Wittig argues "that the category of sex is, under the conditions of compulsory heterosexuality, always feminine (the masculine remaining unmarked and, hence, synonymous with the 'universal')" (Butler, 2006 [1990], p. 25). In the section that more directly discusses relations in language, Butler states that a performative twist of language and/or discourse conceals the fact that "'being' a sex or a gender is fundamentally impossible" (ibid., p. 26). These theoretical considerations offer possible explanations as to why the introduction of the feminine into language (e.g. feminine terms for job titles, social roles, etc., or agents, syntactic agreement with the feminine gender, etc.) often generate new asymmetries, especially in terms of meaning and evaluation.

\section{Discourse and GNL in Education}

The field of education is particularly vulnerable to the transmission and dissemination of ideologies because of the marked "natural" imbalances of power between actors. The final section therefore focuses on the discourse and impact of GNL in education, based on some analyses already conducted and on practices implemented. Pirih Svetina (2012) notes that ideological properties can be attributed to different (linguistic) theories due to their power and influence, which is reflected in language textbooks. Silverstein (1979) argues that linguistic ideology is a "set of beliefs about language articulated by the users as a rationalisation and justification of perceived language structure and use". The historical role of textbooks has changed over the years, but they have always reflected the situation in science and specific philosophical orientations (Čok et al., 1999, pp. 194-198, in Pirih Svetina, 2012, p. 23). Any social ideology is strongly reflected in teaching methods and textbook development, and - of particular importance for GNL - in the transfer of scientific theories into practice and actual (language) use (Pirih Svetina, 2012, p. 23). The problems of gender (in)equality are reflected in at least four basic areas of the pedagogical process that affect the language norm in different ways: gender-sensitive language use in addressing students/pupils, teaching materials, language resources and lexicographic discourse, and (systemic) new stereotyping of social roles through gendered reading lists and other school activities. In the present article, we will only briefly discuss the first 
group, as a great deal has already been said about the problem of the generic use of the masculine gender that significantly influences language use in educational institutions (Gastil, 1990; Bahovec, 1992; Kunst Gnamuš, 1995; Žagar \& Milharčič Hladnik, 1996; Hellinger \& Bussmann, 200I; Hellinger \& Motschenbacher, 2015; Šribar, 2010; Bajić, 2012; Perger, 2016; Kern \& Vičar, 2019, etc.). The role of teaching materials and language resources is also briefly discussed, focusing on the social role of the dictionary, which is remarkably powerful in both language standardisation and GNL.

\section{Gender-Neutral Language in Nomenclatures and Terms of Address}

The origins of GNL in Slovenia and the social climate surrounding it can be traced back to the two-year discussion initiated by European and national authorities (1995-1997) (cf. Umek, 2008, p. 58), which led to a revision of the gendered entries found in the Standard Classification of Occupations (1997). Recent research conducted by Bajić (2012) compared the views and behaviour of Slovenian and Serbian high school students and showed that Slovenian students have a significantly more positive attitude towards this issue than their Serbian counterparts, who have never been exposed to language policies of this kind. Thus, research on the implementation of GNL in Slovenia and Serbia has shown that language policies significantly influence the use and awareness of young speakers (high school students). GNL is considered not only in education, but also in various other areas of public life, such as law (e.g. Štajnpihler Božič, 2019). Although the problem of nomenclatures and naming seems to be the most obvious example, it is in fact one of many levels where gender asymmetry manifests itself. As noted, the most deeply rooted problem arises from gendered address and gendered marking of the symbolic aspects of language. Although expressed in a variety of forms, the latter is equally problematic in many languages (e.g. Hellinger \& Bussman, 20०I).

\section{Teaching Materials}

Another study of GNL in the pedagogical field was conducted by Kranjc (2019, pp. 395-404), who examines pedagogical discourse in language teaching materials on the basis of which students form concepts about gender roles. Kranjc also finds that this is a frequently addressed topic in Slovenia, but that teachers lack adequate guidance on how to increase their sensitivity to GNL. The analysed materials showed that it was rarely possible to avoid stereotypical gender roles intentionally (ibid., pp. 399400). Moreover, many existing Slovenian language teaching materials continue to reflect disproportionate attention devoted to male and female 
authors. Gender-neutral discourse will thus play a crucial role in structuring the fields of literary studies and education in the future, including the reform of the (national) literary canon. These fields may - for now - be free from the imminent threat of "feminisation", but in order to achieve a more gender-balanced representation of literary knowledge they should develop a certain "feminist awareness"; as we know, the creation of gender stereotypes in society is also the result of a ".../ single-sex perception of literature and thus of writing. Such selective exposure to literature can impair adolescents' ability to make critical judgements ... For example, teenage girls are forced to identify with male protagonists, which then carries over into real life ..." (Repar, 2015).

As the representation of women authors in teaching materials is a broad and complex topic, and has therefore been addressed independently, it will not be the focus of the present article (cf. e.g. Mihurko Poniž, 2019; Vendramin, 2018).

\section{Language Resources and Lexicographic Discourse}

Various language resources (dictionaries, grammars, encyclopaedias, etc.) are an important repository of social meaning, although by no means the only one. For example, Gorjanc (2005, 2012, 2017) studied how stereotypes and prejudices about social groups are encoded in Slovenian lexicographic discourse. Dictionaries reflect social values not in the way they are practised, but "on the basis of the current social ideal" (Béjoint, 2000, p. 124, in Gorjanc, 2005, p. 199). In fact, every dictionary is influenced by an ideology, as it reflects social values and introduces the view of the most influential social group in terms of stigmatising and/or discriminating vulnerable groups (e.g. women, homosexuals, immigrants, etc.), which can be indirectly (stereotypes) or directly (insults, swear words) offensive. Furthermore, stereotypes "can lead to offensive references in relation to a particular social group" (Gorjanc, 2005, p. 199), with a focus on women in the present article. While definitions and usage examples can serve to identify explicit and, in particular, covert ideologies (ibid., p. 200), it is this covert nature that is at stake in modern practices of addressing and talking about women, because directly expressing one's ideology or even insulting this particular group is no longer socially acceptable. Gorjanc notes that many directly offensive terms or "negative emotive labels" for women appear in the Dictionary of Standard Slovenian (SSKJ) and even more so in the Slovenian Normative Guide (SP 200I) (e.g. babǐšce (Eng. old bag), gobezdulja (Eng. loudmouth), debeluharica (Eng. fatso)), while also finding some examples of covert sexism (bejba (Eng. chick), etc). The use of these terms is often mislabelled, indicating a lack of social 
responsibility and GNL through the representation of women. Most importantly, these dictionaries do not show actual usage, which can be analysed using contemporary reference corpora (such as Gigafida 2.0 and SIWaC). Thus, the linguistic norm is reflected at the level of the selected dictionary entries, as well as the definitions and usage examples, where the interpretation of reality and the social norm take precedence over grammatical gender. Lexicographic descriptions of meaning and usage play an important role in defining words, such as oseba (Eng. person) or človek (Eng. man/human), in the context of GNL (see especially senses 2 and 4 including examples, below):

člôvek -éka m ed. in dv. (ó ẹ)

1. bitje, ki je sposobno misliti in govoriti: človek in narava; človek se rodi, umrje; te živali se bojijo človeka; anatomija človeka; razlika med človekom in živaljo

2. oseba ne glede na spol ali oseba moškega spola: neki človek stoji pred vrati; ta človek ni priljubljen; našel sem človeka, ki me razume; bližal se je neki bradat, visok človek; pri mizi je prostora še za dva človeka / ekspr. ni ga človeka, ki bi tega ne vedel to vsakdo ve / kot nagovor: človek, kaj pa misliš; ali te ni sram, človek božji / človeka vredno življenje II s prilastkom oseba kot nosilec kake lastnosti: dober človek to rad stori; boj se hinavskega človeka; pameten, pošten človek; star človek tega ne more razumeti / star. popotni človek popotnik / v povedni rabi. čustven, izobražen človek je; saj ni ravno lahkomiseln, slab človek; postal je čisto drug človek

II s prilastkom oseba kot nosilec časovno, krajevno ali kako drugače povezane skupine: mišljenje evropskega,

renesančnega človeka; biti kmečki, mestni človek; slovenski človek / gledališki, poslovni človek / skrb za delovnega človeka

3. ekspr., navadno v povedni rabi kdor združuje $v$ sebi vse pozitivne moralne lastnosti: bodi človek in ne živina; to je človek, to je mož; ni vreden, da se imenuje človek; v vsakem človeku je nekaj človeka

4. nar, s svojilnim zaimkom (zakonski) moż: kje pa je tvoj človek

Picture I: Lexicography at work in gender-(non)neutral language: noun clovek (Eng. human) (Dictionary of Standard Slovenian, second edition $\left(\mathrm{SSKJ}_{2}\right)$ )

A quick look at the lexicographic description of these (lexically and semantically) gender-neutral words may call into question their neutrality in public discourse in which grammatical facts are not considered, where perceptions, intentions and effects of meaning and communication matter more. A dictionary must contain grammatical facts and should convey the actual usage, meaning and pragmatic function of a word in a social context. However, usage examples often reflect the "social reality as seen by lexicographers” (Gorjanc, 2005, p. 205). For comparison, a corresponding dictionary entry from the Oxford-DZS Comprehensive EnglishSlovenian Dictionary (Krek, 2005-6) is shown below to demonstrate attempts of a balanced gender representation policy based on actual usage at the level of entries, definitions and usage examples: 


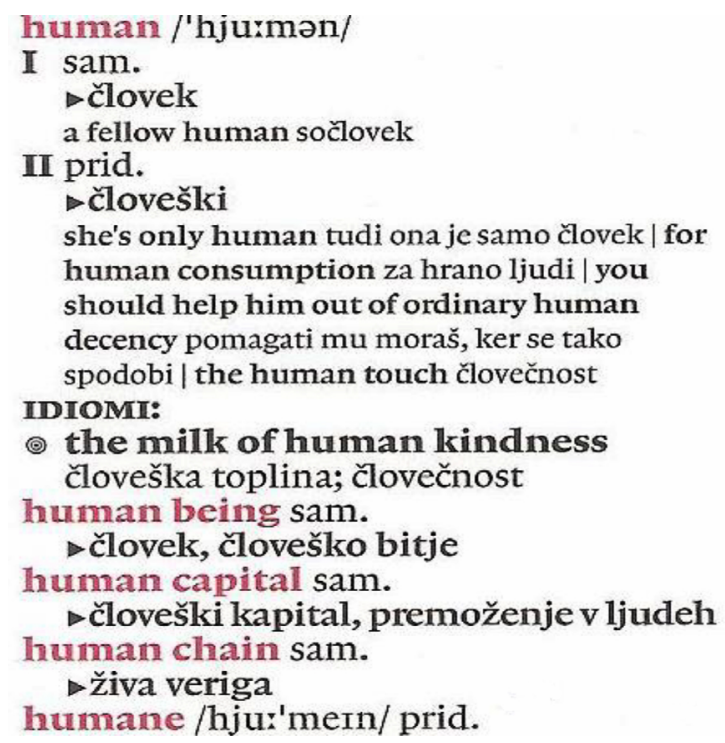

Picture 2: Lexicography at work in gender-(non)neutral language: noun human (The Oxford-DZS Comprehensive English-Slovenian Dictionary)

The systematic definition of feminine agent nouns as derivatives of masculine nouns is another aspect of male-centric language that has been common in foreign language practice (e.g. Béjoint, 2000, pp.133-134, in Gorjanc, 20I2, p. 206). There are 786 instances of the definition "feminine form of" in SSKJ (e.g. asistentka (Eng. teaching assistant), docentka (Eng. assistant professor), državljanka (Eng. (female) citizen), the examples of which are all too often stereotypical or even morally and ethically controversial in the face of social reality. Gorjanc (ibid.) cites, among others, an example with the label "expressive" in "he will beat her black and blue"? In summary, lexicographic discourse has the power to promote or combat harmful ideologies such as sexism, homophobia, racism or anti-immigrant sentiments.

\section{New Stereotyping or Re-Traditionalisation of Social Roles}

In light of what has been said, it is all the more surprising that the practice of entrenching gender roles and stereotypes has expanded in recent decades. One example may be the increasing tendency to separate "books for girls" from "books for boys", as found on reading lists in schools. This trend can be seen equally well in public libraries, where books are divided into "blue" and "pink/red" categories, as found in some young adult 
sections of public libraries. More importantly, this practice is implemented by institutions that, along with schools, have absolute authority over the reading culture of children and young adults, and seems to contradict the goals of promoting gender equality in everyday life (social, professional and economic equality). This reproduces gender stereotypes - especially in terms of evaluative meaning, such as in "the feminisation of education, society, etc." - that perpetuate social inequalities both conceptually and at the level of linguistic expression.

\section{Conclusion}

More in the form of an epilogue than a section proper, the latter theme has highlighted daily experiences that, when evaluated in the context of current social, political and cultural realities, can mean only one thing: regression in the prospects of gender equality and the erosion of already established standards of emancipation. To pursue the goals of equality and resist the erosion of emancipatory practices, different and sometimes diametrically opposed social approaches coded in language use and in teaching materials should be adopted. Solidifying traditional gender roles and gender stereotypes in educational processes counteracts the efforts to make female literary authors more prominent compared to their male counterparts. Moreover, it does not increase sensitivity to issues of social inequality in general or make young girls and boys more aware of physical, psychological and economic violence against the vulnerable, nor does it empower young people to become socially critical individuals. However, language remains a key factor in either achieving or undermining social equality, which is why this issue was given prominence in the present article. The most socially influential groups tend to deny others the right to challenge what is culturally taken for granted in discussions about language and gender. The debate surrounding GNL is clearly less about the language system and more about communicative processes and their social implications. Therefore, the focus is first on language as public discourse: language use is embedded in much broader social (im)balances, with gender construction taking place through and primarily in language. At the same time, the notion of language system cannot be completely bypassed in any debate about language policies, as the levels of language functioning are complex and interdependent. Some typical discourses involving "feminisation" can be identified on the basis of corpus analysis of the relevant contexts, in particular the conception of women's dominance as a deviation from the norm and male dominance as (supposed) neutrality. This discursive phenomenon is analogous to the supposed neutrality of the grammatical norm whereby (male) grammatical gender is 
believed to be immune to the asymmetries found in common social relations. Empirical - i.e. corpus-based - research shows that "feminisation" denotes the process of women "taking over" in many spheres of public life, and is typically associated with negative evaluation. There is a strong perception in society that women increasingly dominate certain areas such as education, law, journalism and health care, and even the military, which is seen as a social problem. As for the discourse analysis of discussions on GNL (e.g. Šorli, 2019; Mikić \& Kalin Golob, 2019), it is worth noting that arguments opposing efforts to reduce male-centric language come from different and even opposing ideological positions, indicating the complex nature of societal perspectives that determine whether GNL would be supported or opposed. However, what really connects the different findings in gender-related theories is symbolic power, which is presented as a universal despite being simply power, which is also discussed by Bourdieu (1991). Another expression similar to many other feminine grammatical forms in that it is devoid of content is "feminine writing" (the French term écriture féminine being a rare exception to the rule), which is mostly used pejoratively to "discredit female writers as 'peculiar' or 'particular' in relation to the 'universal' or supposedly 'gender unmarked' writing of men." This struggle is similar to that taking place in linguistics. Slovenian female author and translator Barbara Simoniti sums it up with the following thought: "I have never heard anyone say that 'William Shakespeare was one of the greatest representatives of male world literature.' Literature is universal - or at least it wants to be. However, it is fascinating that this universal feeling disappears almost instantly when a text is written by a woman."

\section{References}

Antić Gaber, M. (20I4). Biološki/družbeni spol ali kako misliti razmerja socialnega, kulturnega in biološkega. In A. Fausto-Sterling. Biološki/ družbeni spol: biologija v družbi. Krtina.

Bahovec, E. (1992). O feminizmu in psihoanalizi: onstran problema poimenovanja. Problemi-Eseji, 30(I-2), I3I-136.

Bajić, N. (20I2). Spolno (ne)občutljiva raba jezika v Srbiji in Sloveniji v teoriji in praksi. In Ideologija v slovenskem jeziku, literaturi in kulturi, (A collection of articles Seminar slovenskega jezika, literature in kulture, 48) (pp. 124-128). Znanstvena založba Filozofske fakultete.

Béjoint, H. (2000). Modern Lexicography. An Introduction. (Ist edition 1994). Oxford University Press.

8 http://www.cityofwomen.org/sites/default/files/VsakDan8Marec_Slovenscina.pdf 
Bourdieu, P. (1991). Language and Symbolic Power. Polity Press.

Bourdieu, P. (200I). Masculine Domination. Stanford University Press.

Butler, J. (2006 [1990]). Gender Trouble. Feminism and the Subversion of Identity, Routledge.

City of Women (Mesto žensk). http://www.cityofwomen.org/sites/default/ files/VsakDan8Marec_Slovenscina_i.pdf.

Connell, R. (2012). Moškosti. Krtina.

Čok, L., Skela, J., Kogoj, B., \& Razdevšek-Pučko, C. (1999). Učenje in poučevanje tujega jezika:smernice za učitelje $v$ drugem triletju osnovne šle. Pedagoška fakulteta, Znanstveno-raziskovalno središče Republike Slovenije.

Dobrovoljc, H., \& Stabej, M. (2019). Jezikovne izbire v slovenskih smernicah za spolno občutljivo rabo jezika. Slavistična revija, 67(2), 373-384.

Fairclough, N. (1992). Discourse and Social Change. Polity.

Fausto-Sterling, A. (2012). Sex/Gender. Biology in a Social World. Routledge.

Gastil, J. (1990). Generic pronouns and sexist language: The oxymoronic character of masculine generics. Sex Roles, 23, 629-643.

Gilbert, Scott F., 2010: Developmental Biology. Sinauer Associates.

Godina Vuk, V. (2018). Kako globoko so padli tovarišice in tovariši humanisti na FF. Fokuspokus (13. 6. 2018). Retrieved October, I0, 2019, from https://fokuspokus.si/article/3III?=kako-globoko-so-padli-tovarisice-in-tovarisi-humanisti-na-ff.

Gorjanc, V. (2005). Neposredno in posredno žaljiv govor v jezikovnih priročnikih: diskurz slovarjev slovenskega jezika. Družboslovne razprave, 21 (48), 197-209.

Gorjanc, V. (2012). Ideologija heteronormativnosti, prevodna in jezikovna norma. In Ideologija v slovenskem jeziku, literaturi in kulturi (A collection of articles Seminar slovenskega jezika, literature in kulture, 48) (pp. 38-44.). Znanstvena založba Filozofske fakultete.

Gorjanc, V. (2017). Nije rečnik za seljaka. Biblioteka XX vek.

Hellinger, M., \& Bussmann, H. (Eds.) (200I). Gender across languages: the linguistic representation of women and men. John Benjamins.

Hellinger, M., \& Motschenbacher, H. (Eds.) (2015). Gender across languages: the linguistic representation of women and men 4 . John Benjamins.

Jogan, M. (20I8). Izključevanje žensk iz ustvarjanja razumskosti. Dnevnik (18. 8. 2018). Retrieved October I, 2019, from https://www.dnevnik.si/ı042836602/slovenija/ izkljucevanje-zensk-iz-ustvarjanja-razumskosti. 
Kern, B., \& Vičar, B. (2019). Jezik in transspolne identitete. Slavistična revija, $67(2), 413-422$.

Kranjc, S. (2019). Spolno občutljiva raba jezika v učnih gradivih. Slavistična revija, $67(2), 395-404$.

Kress, G. (1989). Linguistic Processes and Sociocultural Practice. Oxford University Press.

Kunst Gnamuš, O. (1994/95). Razmerje med spolom kot potezo reference in spolom kot slovnično kategorijo. Jezik in slovstvo, 4o(7), 255-262.

Lakoff, R. (1975). Language and Woman's Place. Harper \& Row.

Lorber, J. (1994). Paradoxes of Gender. Yale University Press.

Mihurko Poniž, K. (2019). Pravljice starejših slovenskih pisateljic v literarni tradiciji in vzgojno-izobraževalnem sistemu. Jezik in slovstvo, 64(2), 5-I8, II5.

Mikić, J., \& Kalin Golob, M. (2019). (Ne)strpno o spolu: primerjava angleških in slovenskih argumentov proti uvajanju sprememb v seksistični rabi jezika. Slovenščina 2.o: Empirične, Aplikativne in Interdisciplinarne Raziskave, 7(2). 75-117. https://doi.org/10.4312/ slo2.0.2019.2.75-117.

Močnik, R. (2019). Identitetna politika na univerzi. Slavistična revija, 67(2), 355-360.

Money, J., \& Erhardt, A. A. (1972). Man and Woman, Boy and Girl. Johns Hopkins University Press.

Moran, D., \& Mooney, T. (2002). The Phenomenology Reader. Psychology Press.

Nomotehnične smernice (2008). Ljubljana: Uradni list. [Publisher: Služba Vlade Republike Slovenije za zakonodajo].

Okrogla miza Jezik in spol na FF UL 23. 10. 2018. Retrieved October I, 2019, from https://www.youtube.com/watch?v=3DhQQzpoHzA.

Perger, N. (2016). Simbolno nasilje spolnega zaznamovanja v jeziku in prakse upora v visokošolskem prostoru. Družboslovne razprave, 32(8I), 4I-60.

Pirih Svetina, N. (2017). Film, ki mladini »dviga kri« ali kaj je ideološkega v praksi poučevanju jezikov? In Ideologija $v$ slovenskem jeziku, literaturi in kulturi (A collection of articles Seminar slovenskega jezika, literature in kulture, 48) (pp. 2I-28). Znanstvena založba Filozofske fakultete.

Posvet Spol in spostovanje: strategije kultiviranja razlik. The SAZU and FF UL organisations, November 2019, the Great Hall in SAZU. Retrieved April 4, 2020, from http://www.sazu.si/uploads/files/57eereobc2337II 44545f64b/Spol\%2oin\%2ospostovanje_Povzetki.pdf. 
Repar, S. (2015). https://www.rtvslo.si/kultura/drugo/v-ucnih-nacrtih-premalo-slovenskih-avtoric-in-ljudskega-izrocila/368689.

Silverstein, M. (1979). Language structure and linguistic ideology. In R. Cline, W. Hanks \& C. Hofbauer (Eds.), The Elements: A Parasession on Linguistic Units and Levels (pp. 193-247). Chicago Linguistic Society.

Slovar slovenskega knjižnega jezika (SSKJ), I97o-I99I. SAZU, ZRC SAZU and DZS.

Slovenski pravopis (SP). Slovar 200I (2003). CD-ROM. Založba ZRC.

Spender, D. (1980). Man made language. Routledge. Retrieved April 4, 2020, from https://www.marxists.org/reference/subject/philosophy/ works/ot/spender.htm.

Šorli, M. (2019). Spol in jezik na robu pameti: Med slovnico in ideologijo. Slovenščina 2.o. Empirične, aplikativne in interdisciplinarne raziskave, 7(2), 45-74. https://doi.org/10.4312/slo2.0.2019.2.

Šribar, R. (20I8). (Ne)odgovorna znanost: svoboda dela in verjetje v režim. Dialogi, ı. Retrieved October I, 2019, from http://www.aristej.si/slo/ PDF/Dialogi\%2010\%2018\%20Uvod.pdf.

Šribar, R. (2010). Interne smernice za spolno občutljivo rabo jezika. Retrieved December 22, 2020 from http://crtomirkosmrl.xyz/download/9ulrMwEACAAJ-interne-smernice-za-spolno-obcutljivo-rabo-jezika.

Štajnpihler Božič, T. (2019). Spolno občutljiva raba jezika v predpisih. Posvet Spol in spoštovanje: strategije kultiviranja razlik. The SAZU and FF UL organisations, November 2019, the Great Hall in SAZU.

The Oxford-DZS Comprehensive English-Slovenian Dictionary (Ed. S. Krek) (2005-6). DZS.

Toporišič, J. (2000 [1976]). Slovenska slovnica. Založba Obzorja.

Tuldava, J. (1998). Probleme und Methoden der quantitativ-systemischen Lexicologie [1987 in Russian source]. Wissenschaftlicher Verlag.

Umek, N. (2008). Feminizacija v slovenščini in francoščini: družbeni in/ali jezikovni problem? Diplomsko delo. FDV and FF.

Van Dijk, T. A. (2008). Discourse and power. Palgrave Macmillan.

Vendramin, V. (2020). Nekaj epistemoloških zapiskov o raziskovanju spola v edukaciji. In I. Ž. Žagar \& A. Mlekuž (Eds.), Raziskovanje v vzgoji in izobraževanju: mednarodni vidiki vzgoje in izobraževanja (pp. 22I-228.). Pedagoški inštitut, https://www.pei.si/ISBN/978-96I-270324-o.pdf.

Verdonk, P. (2002). Stylistics. Oxford University Press. 
Widdowson, H. (2004). Text, Context, Pretext. Critical Issues in Discourse Analysis. Blackwell.

Wittig, M. (2000). Eseji. ŠKUC.

Žagar, I. Ž., \& Milharčič Hladnik, M. (1996). Nekaj izhodiščnih prizadevanj za odpravo seksistične rabe jezika. In L. Bogovič \& Z. Skušek (Eds.), Spol: Ž. KUD France Prešeren: Institutum Studiorum Humanitatis - ISH. 